九州大学学術情報リポジトリ

Kyushu University Institutional Repository

\title{
Development of Environmental Protection Wood- Based Activated Carbon Fibers Paperboard and its Application in Hygroscopic Ability
}

Lin, Han Chien

Laboratory of Environment Functional Materials, Department of Wood Based Materials and Design, College of Agriculture, National Chiayi University

Liou, Jyun-Fu

Graduate Institute of Forest Products Science and Furniture Engineering, College of Agriculture, National Chiayi University : Master's Program

Lee, Wen-Ju

Graduate Institute of Wood Based Materials and Design, College of Agriculture, National Chiayi University : Master's Program

Wu, She-Ching

Department of Food Science, College of Life Sciences, National Chiayi University

他

https://doi.org/10.5109/1526297

出版情報: 九州大学大学院農学研究院紀要. 60 (1)，pp.163-171，2015-02-27. Faculty of Agriculture, Kyushu University

バージョン：

権利関係 : 


\title{
Development of Environmental Protection Wood-Based Activated Carbon Fibers Paperboard and its Application in Hygroscopic Ability
}

\author{
Han Chien LIN'*, Jyun-Fu LIOU', Wen-Ju LEE ${ }^{3}$, She-Ching WU ${ }^{4}$, \\ Ming-Hong DUH ${ }^{5}$ and Noboru FUJIMOTO
}

\author{
Laboratory of Wood Material Technology, Division of Sustainable Bioresources Science, \\ Department of Agro-environmental Sciences, Faculty of Agriculture, \\ Kyushu University, Fukuoka 812-8581, Japan \\ (Received September 3, 2014 and accepted November 14, 2014)
}

\begin{abstract}
To develop Wood-Based Activated Carbon Fibers Paperboard (WACFP) as a moisture-proof material for food use, Nadelholz/Laubholz Unbleached Kraft Pulp (NUKP/LUKP) and cardboard from recycled cartons were used as precursors for the method of physical activation with steam to prepare activated carbon fibers (ACFs). The ACFs were evaluated by a preliminary safety evaluation (Ames Test) and reverse mutation assay (antimutagenic activity). The Survival (\%) for Salmonella typhimurium TA98 and TA100, with or without the S9 mix (an external metabolic activation system) in the test range $(1.0-5.0 \mathrm{mg} / \mathrm{plate}$ of ACFs), were all higher than those of a blank (control group) by more than 80\%, and the ACFs for TA98 and TA100 with or without S9 did not exceed spontaneous revertants by more than two times, indicating the ACFs had no cytotoxicity or mutagenicity. The antimutagenicity against strains for the ACFs showed an insignificant difference between his ${ }^{+}$revertants and the blank, suggesting the safety of the ACFs used primarily as a material for food use. WACFP was made by adding 10,30 and $50 \mathrm{wt} \%$ of ACFs using the Beating CNS 12495 Method combined with preparation by the Handsheets CNS 11212 Method. The hygroscopic ability of WACFP was investigated. The water activity of all WACFP was from 0.40 to 0.45 . The hygroscopicity of WACFP was $18.74-26.50 \%$ and $5.43-6.36 \%$ for $90 \%$ and $40 \%$ relative humidity (RH), and was lower than that of silica gel, 37.20 and $11.70 \%$. While the hygroscopicity was changed from an $\mathrm{RH} 90 \%$ of absorption to an $\mathrm{RH} 40 \%$ desorption, the percent of desorption for the WACFP was reduced faster than that for silica gel. This can demonstrate that the percent weight of the tested saturated WACFP with different temperature desorptions decreased faster than that of silica gel. As a result, WACFP using ACFs prepared from NUKP, LUKP or cardboard could be a potential moisture-proof material for food use.
\end{abstract}

Key words: Activated Carbon Fibers (ACFs), Ames Test, Wood-Based Activated Carbon Fibers Paperboard (WACFP), Water Activity, Hygroscopic Ability

\section{INTRODUCTION}

Activated carbon fibers (ACFs) are generally regarded as fibrous and porous material that have a large specific surface area, a high adsorption capacity and the ability to regenerate through absorption/desorption (Asakura et al., 2004; Huang, et al., 2010; Liou, 2012). They are widely used as an adsorbent for separating and purifying gaseous or aqueous solutions (Srinivasakannan and Bakar, 2004; Zhang et al., 2004). Moreover, ACFs can provide better characteristics such as a low-pressure drop to mass transfer and high contact efficiency, which is different from powder or granular activated carbon (Asakura et al., 2004). These characteristics are

Laboratory of Environment Functional Materials, Department of Wood Based Materials and Design, College of Agriculture, National Chiayi University, Chiayi, Taiwan, ROC

${ }^{2}$ Master, Graduate Institute of Forest Products Science and Furniture Engineering, College of Agriculture, National Chiayi University, Chiayi, Taiwan, ROC

Master, Graduate Institute of Wood Based Materials and Design, College of Agriculture, National Chiayi University, Chiayi, Taiwan, ROC

${ }^{4}$ Department of Food Science, College of Life Sciences, National Chiayi University, Chiayi, Taiwan, ROC

${ }^{5}$ Department of Wood Based Materials and Design, College of Agriculture, National Chiayi University, Chiayi, Taiwan, ROC

* Corresponding author (E-mail: alexhlin@mail.ncyu.edu.tw) due to their fibrous shape with a high aspect ratio, and ACFs prepared from softwood consisting mostly of micropores, as well as mesopores and macropores were formed in the case of the hardwood fiber (Asakura et al., 2004; Huang, et al., 2010).

Previous work established that ACFs could be prepared by physical methods with steam activation from Nadelholz/Laubholz Unbleached Kraft Pulps and cardboard from recycled cartons. SEM observation of the ACFs showed that the hollow structures and some of the pits from the fibers still rested after wood pulps or paper wastes were processed at a higher temperature. The yield of all ACFs was 6.29 to $14.35 \%$, the range in iodine values was between 635.45 and $1077.72 \mathrm{mg} / \mathrm{g}$ and the methylene blue adsorption value was about 268.33 to 504.03 (mg/g) (Huang et al., 2010). It is well known that the hollow structure and good absorption of various activated carbons can be prepared from a natural material and can provide a functional adsorbent material, especially for a moisture-proof material for food use, such as: placed in salt, pepper or flavoring jars to keep them dry and prevent deliquescence and foreign flavor, or as a treatment process, e.g. purifying drinking water and conserving medical drugs (Liou, 2012; Lin, et al., 2014a; Lin, et al., 2014b). However, ACFs are a type of fibrous material with a shape between powder and granular activated carbon. This is inconvenient for placing with food con- 
sidering the dimension and shape of ACFs; even if they have excellent absorption performance.

Therefore, the study attempted to develop a type of food's moisture-proof material with a paper shape. Safety should be considered when comparing the commercial moisture-proof material, silica gel and calcium oxide $(\mathrm{CaO})$ because the appearance of silica gel is a transparent particle which can be eaten as crystal sugar, possibly resulting in uncomfortable pain, and for $\mathrm{CaO}$ it is white or gray-white with toxicity, that, if eaten, results in an illness of the intestines and stomach (National Poison Center, 1990). Nevertheless, ACFs as a food's moistureproof material will probably be in contact with food directly or indirectly, and could even be eaten. It is necessary to undergo a genotoxicity study (Ames Test) in accordance with Item 2, Article 3 of the Health Food Control Act and the Health Food Safety Assessment Method specified in W.S.S.Z. No. 88037803 announcement from the Ministry of Health and Welfare, 1999.

The objectives of the study were to evaluate the Salmonella mutagenesis assay (Ames Test) and reverse mutation assay (antimutagenic activity) of ACFs first and to develop a food moisture-proof material, WoodBased Activated Carbon Fibers Paperboard (WACFP) with different percent weights of ACFs. WACFP was made by using the method of Beating CNS (Chinese National Standards) 12495 combined with the method of preparation of Handsheets CNS 11212. To gauge the effectiveness of moisture-proof material, the hygroscopic ability of WACFP was investigated, including water activity (Aw), hygroscopicity with either a higher or lower relative humidity at a specific temperature and the effect of absorption and desorption. This study uses wood pulp and paper wastes as the precursors to develop the products - WACFP with ACFs - that can provide a moistureproof application for food to increase their value.

\section{MATERIALS AND METHODS}

\section{Specimen preparation and characterization}

\section{Precursor}

Nadelholz/Laubholz Unbleached Kraft Pulps (NUKP/ LUKP) paperboard was provided by the Hou-li Mill, Cheng Loong Corporation in Taiwan. Cardboard from recycled cartons without a printing process was collected. The specimens, NUKP/LUKP paperboards and cardboard, with dimensions of $20 \mathrm{~mm} \times 20 \mathrm{~mm}$ were prepared and then, defibrillated by a grinder to be used as the precursor. The basic properties and morphological characteristics of the specimens refer to (Huang, et al., 2010; Liou, 2012).

\section{Test strains}

Salmonella typhimurium (S. typhimurium) TA98 and TA100 were bought from the Bioresource Collection and Research Center, Food Industry Research and Development Institute.

Rat liver mixture

One of the enzymes in a rat liver mixture (S9 mix), as an external metabolic activation system, was prepared from Sprague-Dawley male rats treated with Aroclor
1254 (Organ Teknika Co., Switzerland).

Mutagens

The mutagens were 4-nitroquinoline-N-oxide (NQNO), a direct mutagen and the mutagenicity of aflatoxin $\mathrm{B}_{1}\left(\mathrm{AFB}_{1}\right)$, an indirect mutagen which requires metabolic activation. They were obtained from the Sigma Chemical Co. (Steinheim, Germany). All reagents used in the test were of analytical grade.

Preparation of activated carbon fibers (ACFs)

The precursor, $20 \mathrm{~g}$ of absolute dried specimen, was refined in a closed container of super-high temperature vacuum carbonization activation equipment (Chi-How Heating Co., Ltd.). Nitrogen $\left(\mathrm{N}_{2}\right.$ gas) was added to make the container oxygen free. The heating rate was set at $10^{\circ} \mathrm{C} / \mathrm{min}$, and the specimen was heated to the carbonization temperature of $800^{\circ} \mathrm{C}$. The activation temperature was carried out at $800^{\circ} \mathrm{C}$ with an activation duration of $60 \mathrm{~min}$. The steam was maintained at a flow rate of $1 \mathrm{~L} / \mathrm{h}$. The ACFs were then cooled by $\mathrm{N}_{2}$ gas to a normal temperature and taken out. The preparation ACFs code was ACFs-precursor (N: NUKP; L: LUKP; R: cardboard) activation temperature, such as ACFs-N800 (Table 1). The aforesaid preparation conditions refer to (Huang et al., 2010). The equation for the ACFs yield (Y) is $\mathrm{Y}(\%)=$ (absolute dry weight of ACFs/absolute dry weight of test precursor) $\times 100$.

Iodine value

The iodine values of the ACFs were measured according to the Japanese Industrial Standard (JIS) K 1474 (1991) Test Methods for Activated Carbon. The formula for iodine adsorption capacity is: $\mathrm{I}=[(10-\mathrm{K} \times \mathrm{f}) \times$ $12.69 \times 5$ ] $/ \mathrm{M}$. The abbreviations for the formula are I: iodine adsorption capacity $(\mathrm{mg} / \mathrm{g})$; $\mathrm{K}$ : the volume of titrated sodium thiosulfate $(\mathrm{mL})$; f: the ratio of $0.1 \mathrm{~N}$ sodium thiosulfate to $0.1 \mathrm{~N}$ iodine solution, and $\mathrm{M}$ : the weight of absolute dried ACFs ( $0.5 \mathrm{~g})$.

Porosity measurements

The pore structure characteristics of the resulting ACFs were determined by $\mathrm{N}_{2}$ gas adsorption at $77 \mathrm{~K}$ with an automated adsorption instrument (BET-202A, Porous Materials, Inc.) in a relative pressure $(P / P O)$ ranging from $10^{-2}$ to 1 . The BET specific surface areas $\left(\mathrm{S}_{\mathrm{BET}}\right)$ of the ACFs were analyzed by the standard BET equation and its procedure developed by Barrett et al. (1951). The total pore volume (Vtot) was obtained by converting the amount of $\mathrm{N}_{2}$ gas adsorbed (expressed in $\mathrm{cm}^{3} / \mathrm{g}$ STP) at a relative pressure of 0.99 to the volume of liquid adsorbate. The average pore diameter ( $\mathrm{D}=4$ Vtot / $\mathrm{S}_{\mathrm{BET}}$ ) was calculated (Hu and Srinivasan, 1999).

\section{Ames Test}

Cytotoxicity

1.0, 2.5 and $5.0 \mathrm{mg}$ of the ACFs were examined with S. typhimurium TA98 and TA100 for either S9 mix (+S9) or zero S9 (-S9) in accordance with the Ames Test and the experimental procedure referred to by Ames et al. (1975). The colony count was calculated; if the bacterial count of the test group (+S9 or -S9) was greater than the bacterial count of the control group (no specimen; blank) by 80\% (Survival), there was no cytotoxic- 
ity. The formula used was Survival (\%) = (the bacterial count of test group/the bacterial count of control group) * 100 .

\section{Mutagenicity}

The mutagenicity was analyzed by using the method proposed by Maron and Ames (1983). The test dose selected for this mutagenicity test with +S9 or -S9 was the same as the aforesaid cytotoxicity test. The test for mutagenicity was carried out at $37^{\circ} \mathrm{C}$ for $48 \mathrm{~h}$, and the phosphate buffer saline was used as the control group (blank). The detailed procedures refer to (Tseng, et al., 2010; Liou, 2012). If the colony count of the TA98 and TA100 test group was greater than the blank by more than two times; that is, the Mutagenicity Ratio was larger than 2, the ACFs were considered to have mutagenicity. The Mutagenicity Ratio (MR) = induced revertants per plate/spontaneous revertants per plate (blank).

\section{Antimutagenic activity}

The ACFs of the antimutagenic activity were assayed according to the Ames Method (Maron and Ames, 1983). The mutagens that were diluted with dimethyl sulfoxide (DMSO) were NQNO (1 $\mu \mathrm{g} /$ plate for TA98 or TA100) and $\mathrm{AFB}_{1}(5 \mu \mathrm{g} / \mathrm{plate}$ for TA98 or TA100), which required an S9 mix for metabolic activation. A mutagen $(0.1 \mathrm{~mL}$; contained $1 \mu \mathrm{g}$ NQNO or $5 \mu \mathrm{g} \mathrm{AFB}_{1}$ ) was added to $S$. typhimurium TA 98 or TA 100, and 1.0, 2.5 and $5.0 \mathrm{mg}$ of the ACFs were added to the S9 mix for NQNO or $\mathrm{AFB}_{1}$ to the phosphate buffer $(0.1 \mathrm{~mol} / \mathrm{L}, \mathrm{pH} 7.4)$. The test for antimutagenicity was carried out at $37^{\circ} \mathrm{C}$ for $48 \mathrm{~h}$. The detailed procedures refer to (Liou, 2012; Lin, et al., 2014a). The mutagenicity of each mutagen in the absence of an extract is defined as 100\%. The inhibition (\%) of mutagenicity for ACFs is calculated as follows:

Inhibition $(\%)=\left[1-\left(\right.\right.$ Number of his ${ }^{+}$revertants in the presence of ACFs - Number of spontaneous revertants)/(Number of his $^{+}$revertants in the absence of ACFs - Number of spontaneous revertants)] $\times 100$

\section{Development of Wood-based activated carbon fib- ers paperboard (WACFP)}

This developed method of WACFP was designed by the Laboratory of Environmental Functional Materials, Department of Wood-Based Materials, National Chiayi University in Taiwan. WACFP, based on $360 \mathrm{~g} / \mathrm{cm}^{2}$, with ACFs was made by using the method of Beating Chinese National Standards (CNS) 12495 combined with the method of preparation of Handsheets CNS 11212. During the method of CNS 12495, NUKP 20\% and LUKP 80\% were mixed with different percent weights (\%) of ACFs, adding 10, 30 and $50 \mathrm{wt} \%$. The aforesaid detailed steps refer to (Liou, 2012). The developing WACFP code was WACFP-precursor (N: NUKP; L: LUKP; R: Cardboard) percent weight (\%) of ACFs. The abbreviation for each WACFP is shown in Table 1.

\section{Hygroscopic Ability of WACFP \\ Water activity (Aw)}

The Aw of the WACFP was determined using the Test for Water Activity of Food, and the procedure was
Table 1. Abbreviation of each wood-based activated carbon fiber paperboard

\begin{tabular}{rcc}
\hline Specimens & ACFs (wt\%) & Abbreviation of WACFP ${ }^{1)}$ \\
\hline \multirow{2}{*}{ ACFs-N800 $^{2)}$} & 10 & WACFP-N10 \\
& 30 & WACFP-N30 \\
& 50 & WACFP-N50 \\
\hline \multirow{2}{*}{ ACFs-L800 } & 10 & WACFP-L10 \\
& 30 & WACFP-L30 \\
& 50 & WACFP-L50 \\
ACFs-R800 & 10 & WACFP-R10 \\
& 30 & WACFP-R30 \\
& 50 & WACFP-R50
\end{tabular}

1) WACFP: Wood-based activated carbon fiber paperboard

2) ACFs (activated carbon fibers) - precursor (N: NUKP; L: LUKP; R: cardboard from recycled cartons) - Activated temperature

3) WACFP - precursor (N: NUKP; L: LUKP; R: Cardboard from recycled cartons) - percent weight of ACFs

determined in consultation with the CNS 5255 (1987). Six replicates of each specimen for either the WACFP or silica gel were investigated.

Hygroscopicity

Each WACFP weighing $3 \mathrm{~g}$ was placed in a bottle without a top. The hygroscopicity of the WACFP was examined in each measured point after a certain period of time, 2, 4, 6, 10, 16, 24, 48, 72, 96 and $114 \mathrm{~h}$, with either a higher relative humidity $(\mathrm{RH})$ at $90 \%$ or a lower $\mathrm{RH}$ at $40 \%$ at a specific temperature of $25^{\circ} \mathrm{C}$ (Lin et al., 2014a). The maximum percent weight (\%) under either of the aforesaid conditions for the WACFP and silica gel was investigated.

Absorption and desorption

$3 \mathrm{~g}$ of an absolute dried specimen of WACFP and silica gel were put in a program-adjusted conditioner (TERCHY HRM Co., Ltd.). A specific temperature of $25^{\circ} \mathrm{C}$ with a higher $\mathrm{RH}$ at $90 \%$ was set. The specimens were measured for percent weight of absorption during a period of time, 2, 4, 6, 10, 16, 24, 48, 72, 96 and $114 \mathrm{~h}$, respectively. After that, the resulting specimens were continuous in the conditioner, but a lower RH $40 \%$ with a specific temperature of $25^{\circ} \mathrm{C}$ was altered automatically, and the percent weight of desorption was measured at the same aforementioned periods of time. The percent of absorption and desorption for the WACFP or silica gel was calculated as follows. The formula is: percent of absorption and desorption (\%) = [(the weight of absorption or desorption of specimen - the absolute dried weight of specimen)/the absolute dried weight of specimen] $\times$ 100. The curve for the percent of absorption and desorption of the WACFP or silica gel was sketched. Desorption state with different temperatures

To demonstrate that the desorption of WACFP and silica gel was influenced by the absorption state with a higher $\mathrm{RH}$ to the desorption state at a lower $\mathrm{RH}, 3 \mathrm{~g}$ of absolute dried WACFP and silica gel were adjusted to become a saturated situation with a RH $90 \%$ or $40 \% \mathrm{RH}$ 
in the conditioner. The weight of the specimens was individually measured as $100 \%$ of the percent weight, and then, was put at different temperatures (60, 80 and $100^{\circ} \mathrm{C}$ ) in an oven. The percent weight of desorption for the WACFP and silica gel was measured at a series of certain periods. The resulting curves of the percent weights for the WACFP or silica gel were compared.

\section{Statistical analysis}

The test results are represented by a mean (standard deviation), and the control group (blank) and test group are compared by Duncan's Analysis. If the $\rho$ value is smaller than 0.05 , meaning a significant difference between the test group and the control group, it is represented by different superscript upper case letters.

\section{RESULTS AND DISCUSSION}

\section{Yield, iodine value and porosity of ACFs}

As shown in Table 2, the yields of the activated carbon fibers (ACFs) ranged from 10.85 to $13.66 \%$ for NUKP/ LUKP and cardboard prepared at carbonization temperatures of $800^{\circ} \mathrm{C}$ with the carbonization duration of $60 \mathrm{~min}$. The iodine values of ACFs ranged from 647.38 to $1060.97 \mathrm{mg} / \mathrm{g}$. The highest iodine value, $1060.87 \mathrm{mg} / \mathrm{g}$, of ACFs was obtained from NUKP. Commercial activated carbons produce iodine values normally ranging from 600 to $1000 \mathrm{mg} / \mathrm{g}$ (Hu and Srinivasan, 1999). The iodine values of the resulting ACFs are similar to the commercial values and denoted indicators of micropore amounts (Chen, 2003) because the diameter of iodine molecules was $0.56 \mathrm{~nm}$ (Hsieh and Teng, 1999). Micropores, with pore size diameters less than $2 \mathrm{~nm}$, have been classified by the International Union of Pure and Applied Chemistry (IUPAC).

The $\mathrm{S}_{\mathrm{BET}}$ and pore characteristics of ACFs from various precursors are also shown in Table 2 . The $\mathrm{S}_{\mathrm{BET}}$ and Vtot of ACFs-N800 and -L800, exhibiting the higher values of $779.12-877.21 \mathrm{~m}^{2} / \mathrm{g}$ and $0.90 \mathrm{~cm}^{3} / \mathrm{g}$, were higher than those of ACFs-R800, $262.03 \mathrm{~m}^{2} / \mathrm{g}$ and $0.35 \mathrm{~cm}^{3} / \mathrm{g}$. Commercial activated carbons exhibited $\mathrm{S}_{\mathrm{BET}}$ values ranging from 500 to $2000 \mathrm{~m}^{2} / \mathrm{g}$ (Williams and Reed, 2006). Wang (2004) reported that the greater the surface areas, the better the adsorption became, indicating that the adsorption of ACFs-N800 and -L800 is greater than that of ACFs-R800. The percentage of Vmi/Vtot showed that ACFs-N800 had many more micropores (31.5\%) than ACFs-L800 and ACFs-R800, 22.5 and 15.0\%. Physical activation had pore-drilling and expansion effects at $800^{\circ} \mathrm{C}$ producing multiple micropores (Lua and Guo, 2000; Yun et al., 2001). The average pore diameters of ACFs-L800 were $4.11 \mathrm{~nm}$, greater than those of ACFs-N800 at $2.14 \mathrm{~nm}$. This is because softwood ACFs consist mostly of micropores and hardwood ACFs resulted in meso- and macropores as well as micropores being formed (Asakura et al., 2004; Huang, et al., 2010).

\section{Cytotoxicity and mutagenicity of ACFs}

Ames et al. (1975) reported that for screening of environmental mutagens and carcinogens, the Ames Test, a convenient method to evaluate mutagenic activities of these chemicals, has been developed, and a mistake in the results of mutagenicity occurred due to the decrease in the residual bacterial count with cytotoxicity. Moreover, McCann et al. (1975) and Shugimura et al. (1976) have suggested that the mutagenic activities of a number of chemicals correlate well with the carcinogenic activities. The cytotoxicity of ACFs therefore, has to be determined before testing the mutagenicity of ACFs. Cytotoxicity results for the ACFs prepared from three types of precursors and silica gel with amounts of 1.0, 2.5 and $5.0 \mathrm{mg} /$ plate for $S$. typhimurium TA98 and TA100 without the S9 mix, as well as with the S9 mix are shown in Table 3.

The residual bacterial count of the control group (blank) for S. typhimurium TA98 and TA100 without the S9 mix was 2638 and 2630, and with the S9 mix was 2985 and 2781. For silica gel, the residual bacterial count without S9 was 2607-2714 for TA98 and 2548-2983 for TA100; for those with S9, it was 2807-3142 for TA98 and 2679-2863 for TA100. For all ACFs, the range of the residual bacterial count without S9 was 2472-2740 for TA98 and 2607-2691 for TA100, and with S9 was 28983132 for TA98 and 2705-2904 for TA100. Waleh et al. (1982) indicated that the residual bacteria rate of $S$. typhimurium must be over $80 \%$ of the control group to determine whether the test group has no cytotoxicity for S. typhimurium. The residual bacteria rate (Survival,

Table 2. Yield, iodine value and porosity of activated carbon fibers prepared from various precursors with $800^{\circ} \mathrm{C}$ activated temperature

\begin{tabular}{|c|c|c|c|c|c|c|}
\hline Specimen & $\begin{array}{l}\text { Yield } \\
(\%)\end{array}$ & $\begin{array}{l}\text { Iodine value } \\
\text { (mg/g) }\end{array}$ & $\begin{array}{l}\mathrm{S}_{\mathrm{BET}}^{1)} \\
\left(\mathrm{m}^{2} / \mathrm{g}\right)\end{array}$ & $\begin{array}{l}V \operatorname{tot}^{2)} \\
\left(\mathrm{cm}^{3} / \mathrm{g}\right)\end{array}$ & $\begin{array}{c}V \mathrm{mi}^{3)} / V \text { tot } \\
(\%)\end{array}$ & $\begin{array}{c}\mathrm{D}^{4)} \\
(\mathrm{nm})\end{array}$ \\
\hline ACFs-N800 5) & $\begin{array}{c}11.38 \\
(0.35)^{6)}\end{array}$ & $\begin{array}{r}1060.97 \\
(1.74)\end{array}$ & 779.12 & 0.90 & 31.5 & 2.14 \\
\hline ACFs-L800 & $\begin{array}{l}10.85 \\
(0.25)\end{array}$ & $\begin{array}{l}912.03 \\
(17.04)\end{array}$ & 877.21 & 0.90 & 22.5 & 4.11 \\
\hline ACFs-R800 & $\begin{array}{l}13.66 \\
(0.22)\end{array}$ & $\begin{array}{l}647.38 \\
(26.11)\end{array}$ & 262.03 & 0.35 & 15.0 & 5.38 \\
\hline
\end{tabular}

${ }^{1)} \mathrm{S}_{\text {BET }}$ : specific surface area; ${ }^{2)}$ Vtot: total pore volume; ${ }^{3)}$ Vmi: micropore volume; ${ }^{4)} \mathrm{D}$ : average diameter of pore $\left(4\right.$ tot $\left./ \mathrm{S}_{\mathrm{BET}}\right) ;{ }^{5)}$ Abbreviations see the Table $1 ;{ }^{6)}$ Mean (standard deviation) 
\%) for TA98 and TA100 for all ACFs and silica gel was higher than for the control by more than $80 \%$. This indicates that ACFs and silica gel have no cytotoxicity for the test strains in the additional range of $1.0-5.0 \mathrm{mg} / \mathrm{plate}$, and the dose for the mutagenicity test can be selected according to this range.

Table 4 shows the mutagenicity test results for ACFs and silica gel for $S$. typhimurium TA98 and TA100. The spontaneous revertants of the blank for $S$. typhimurium TA98 and TA100 without the S9 mix were 46

Table 3. Cytotoxicity of silica gel and various ACFs toward Salmonella typhimurium TA98 and TA100 without the S9 (-S9) or with the S9 (+S9) mix

\begin{tabular}{|c|c|c|c|c|c|c|c|c|c|}
\hline \multirow[b]{2}{*}{ Specimen } & \multirow{2}{*}{$\begin{array}{l}\text { Amount } \\
\text { (mg/plate) }\end{array}$} & \multicolumn{4}{|c|}{ - S9 } & \multicolumn{4}{|c|}{$+\mathrm{S} 9$} \\
\hline & & TA98 & $\begin{array}{l}\text { Survival }^{1)} \\
(\%)\end{array}$ & TA100 & $\begin{array}{c}\text { Survival } \\
(\%)\end{array}$ & TA98 & $\begin{array}{c}\text { Survival }^{1)} \\
(\%)\end{array}$ & TA100 & $\begin{array}{c}\text { Survival } \\
(\%)\end{array}$ \\
\hline blank $^{2)}$ & 0.0 & $2638(97)^{\text {abc } 3)}$ & 100 & $2630(108)^{\mathrm{a}}$ & 100 & $2985(103)^{\mathrm{abc}}$ & 100 & $2781(133)^{\mathrm{abc}}$ & 100 \\
\hline \multirow{3}{*}{ Silica gel } & 1.0 & $2607(104)^{\mathrm{a}}$ & 99 & $2722(97)^{\mathrm{a}}$ & 103 & $2807(95)^{\mathrm{a}}$ & 94 & $2863(164)^{\mathrm{a}}$ & 103 \\
\hline & 2.5 & $2714(86)^{\mathrm{a}}$ & 103 & $2983(105)^{b}$ & 113 & $2852(168)^{\mathrm{a}}$ & 96 & $2748(103)^{\mathrm{ac}}$ & 99 \\
\hline & 5.0 & $2684(108)^{\mathrm{a}}$ & 102 & $2548(124)^{\mathrm{a}}$ & 97 & $3142(115)^{\mathrm{b}}$ & 105 & $2679(99)^{\mathrm{a}}$ & 96 \\
\hline \multirow{3}{*}{ ACFs-N800 ${ }^{4)}$} & 1.0 & $2548(84)^{\mathrm{ab}}$ & 97 & $2643(71)^{\mathrm{a}}$ & 100 & $2929(81)^{\mathrm{abc}}$ & 98 & $2827(107)^{\text {abc }}$ & 102 \\
\hline & 2.5 & $2472(101)^{\mathrm{a}}$ & 94 & $2607(86)^{\mathrm{a}}$ & 99 & $2931(96)^{\mathrm{abc}}$ & 98 & $2721(83)^{\mathrm{abc}}$ & 98 \\
\hline & 5.0 & $2604(98)^{\mathrm{abc}}$ & 99 & $2680(88) \mathrm{a}$ & 102 & $2848(129)^{\mathrm{a}}$ & 95 & $2852(95)^{\mathrm{abc}}$ & 103 \\
\hline \multirow{3}{*}{ ACFs-L800 } & 1.0 & $2486(106)^{\mathrm{a}}$ & 94 & $2663(66)^{\mathrm{a}}$ & 101 & $3058(137)^{\text {abc }}$ & 102 & $2904(94)^{c}$ & 104 \\
\hline & 2.5 & $2696(103)^{\mathrm{bc}}$ & 102 & $2674(84)^{\mathrm{a}}$ & 102 & $2898(94)^{\mathrm{ab}}$ & 97 & $2820(81)^{\mathrm{abc}}$ & 101 \\
\hline & 5.0 & $2590(86)^{\mathrm{abc}}$ & 98 & $2657(94)^{\mathrm{a}}$ & 101 & $3132(112)^{c}$ & 105 & $2754(149)^{\text {abc }}$ & 99 \\
\hline \multirow{3}{*}{ ACFs-R800 } & 1.0 & $2712(98)^{\text {bc }}$ & 103 & $2691(104)^{a}$ & 102 & $2903(82)^{\mathrm{ab}}$ & 97 & $2639(122)^{\mathrm{a}}$ & 95 \\
\hline & 2.5 & $2740(92)^{\text {bc }}$ & 104 & $2648(100)^{\mathrm{a}}$ & 101 & $3102(94)^{\mathrm{bc}}$ & 104 & $2705(109)^{\text {abc }}$ & 97 \\
\hline & 5.0 & $2574(76)^{\mathrm{ab}}$ & 98 & $2661(67)^{\mathrm{a}}$ & 101 & $2965(76)^{\text {abc }}$ & 99 & $2843(95)^{\mathrm{abc}}$ & 102 \\
\hline
\end{tabular}

1) Survival $(\%)=($ the bacterial count of test group / the bacterial count of control group) $* 100$

${ }^{2}$ blank (the control group) : the specimen was without silica gel or ACFs

${ }^{3)}$ Mean (standard deviation) within a transverse with the different superscripts are significantly different $(\rho<0.05)$ by Duncan's multiple range tests

4) Abbreviations see the Table 1

Table 4. Mutagenicity of silica gel and various ACFs toward Salmonella typhimurium TA98 and TA100 without the S9 (-S9) or with the S9 (+S9) mix

\begin{tabular}{|c|c|c|c|c|c|c|c|c|c|}
\hline \multirow{2}{*}{ Specimen } & \multirow{2}{*}{$\begin{array}{c}\text { Amount } \\
\text { (mg/plate) }\end{array}$} & \multicolumn{4}{|c|}{$-\mathrm{S} 9$} & \multicolumn{4}{|c|}{$+\mathrm{S} 9$} \\
\hline & & TA98 & $\mathrm{MR}^{1)}$ & TA100 & MR & TA98 & MR & TA100 & MR \\
\hline blank $^{2)}$ & 0.0 & $46(2)^{\mathrm{abc} 3)}$ & 1.00 & $156(06)^{\text {abcd }}$ & 1.00 & $55(6)^{\mathrm{abc}}$ & 1.00 & $160(8)^{\mathrm{ab}}$ & 1.00 \\
\hline \multirow{3}{*}{ Silica gel } & 1.0 & $38(4)^{a}$ & 0.83 & $182(20)^{\mathrm{b}}$ & 1.17 & $57(7)^{c}$ & 1.04 & $184(12)^{\mathrm{b}}$ & 1.15 \\
\hline & 2.5 & $43(3)^{\mathrm{ab}}$ & 0.93 & $132(12)^{\mathrm{a}}$ & 0.85 & $33(4)^{\mathrm{a}}$ & 0.60 & $176(8)^{\mathrm{ab}}$ & 1.10 \\
\hline & 5.0 & $58(3)^{c}$ & 1.26 & $174(18)^{\mathrm{b}}$ & 1.12 & $45(8)^{b}$ & 0.82 & $181(17)^{\mathrm{ab}}$ & 1.13 \\
\hline \multirow{3}{*}{ ACFs-N800 ${ }^{4)}$} & 1.0 & $44(3)^{\mathrm{ab}}$ & 0.95 & $164(07)^{\text {bcde }}$ & 1.05 & $54(5)^{\text {abc }}$ & 0.99 & $154(6)^{\mathrm{a}}$ & 0.96 \\
\hline & 2.5 & $48(3)^{\mathrm{abc}}$ & 1.03 & $168(05)^{\mathrm{de}}$ & 1.07 & $57(4)^{\mathrm{abc}}$ & 1.04 & $165(4)^{\text {abcd }}$ & 1.03 \\
\hline & 5.0 & $44(2)^{\mathrm{ab}}$ & 0.95 & $156(08)^{\text {abcd }}$ & 1.00 & $54(3)^{\mathrm{abc}}$ & 0.99 & $161(8)^{\mathrm{abc}}$ & 1.01 \\
\hline \multirow{3}{*}{ ACFs-L800 } & 1.0 & $48(3)^{\mathrm{abc}}$ & 1.05 & $154(05)^{\mathrm{abc}}$ & 0.99 & $58(2)^{a}$ & 1.06 & $175(5)^{\text {cde }}$ & 1.09 \\
\hline & 2.5 & $46(4)^{\mathrm{abc}}$ & 1.01 & $161(09)^{\text {abcde }}$ & 1.03 & $59(4)^{\mathrm{abc}}$ & 1.08 & $172(4)^{\text {bcde }}$ & 1.08 \\
\hline & 5.0 & $46(2)^{\mathrm{abc}}$ & 1.00 & $151(05)^{\mathrm{ab}}$ & 0.97 & $52(2)^{\mathrm{abc}}$ & 0.95 & $160(7)^{\mathrm{ab}}$ & 1.00 \\
\hline \multirow{3}{*}{ ACFs-R800 } & 1.0 & $52(4)^{c}$ & 1.13 & $152(09)^{\mathrm{ab}}$ & 0.98 & $53(2)^{\mathrm{ab}}$ & 0.97 & $171(4)^{\text {bcde }}$ & 1.07 \\
\hline & 2.5 & $47(3)^{\mathrm{a}}$ & 1.01 & $150(06)^{\mathrm{a}}$ & 0.96 & $57(5)^{\mathrm{abc}}$ & 1.03 & $162(7)^{\text {abcd }}$ & 1.01 \\
\hline & 5.0 & $45(4)^{\mathrm{abc}}$ & 0.97 & $168(08)^{\text {de }}$ & 1.08 & $55(4)^{\mathrm{abc}}$ & 1.01 & $160(10)^{\mathrm{ab}}$ & 1.00 \\
\hline
\end{tabular}

1) MR (Mutagenicity ratio) = induced revertants per plate/spontaneous revertants per plate (Blank)

2) blank (the control group) : the specimen was without silica gel or ACFs

3) Mean (standard deviation) within a transverse with the different superscripts by Duncan's multiple range tests at 5\% significant level

4) Abbreviations see the Table 1 
and 156 , and 55 and 160 for TA98 and TA100 with the S9 mix. For silica gel, the spontaneous revertants with amounts of $1.0,2.5$, and $5.0 \mathrm{mg} /$ plate without S9 were 38-58 for TA98 and 132-182 for TA100; for those with S9, they were 33-57 for TA98 and 176-184 for TA100. For all ACFs, the range of the spontaneous revertants without S9 was 44-52 for TA98 and 150-168 for TA100, and with S9 was 52-59 for TA98 and 154-175 for TA100. The results also showed that the specimens, with or without $\mathrm{S} 9$, in the test range (1.0-5.0 mg/plate) did not exceed spontaneous revertants by more than two times for TA98 and TA100. In other words, the Mutagenicity Ratio (MR) was smaller than 2. According to the standards proposed by Ames et al. (1975), if the number of spontaneous revertants induced by the specimen is greater than the spontaneous revertants of the control group by more than two times, the specimen has mutagenicity. Therefore, the ACFs and silica gel have no mutagenicity toward S. typhimurium TA98 and TA100 without the S9 and with the S9.

\section{Antimutagenicity of ACFs}

$\mathrm{ACF}$ is one material for developing WACFP, regarding a moisture-proof material, in this study. The WACFP can easily contact the food directly or indirectly. Therefore, the antimutagenic activity of the ACFs was investigated. This is because the antimutagenic properties have an array of prospective applications in human care, such as the increasing application in drinks, food antioxidation, etc., and have not been reported for the antimutagenic activities of ACFs that have been made so far.

In the present study, NQNO and AFB1 were used as direct mutagens requiring metabolic activation and indirect acting mutagen, respectively. Doses of mutagens, $1 \mu \mathrm{g}$ for $\mathrm{NQNO}$ and $5 \mu \mathrm{g}$ for $\mathrm{AFB}_{1}$, were selected from a dose-response curve of a preliminary experiment (Yen et al., 2001). The inhibitory effect of the specimen is expressed by inhibition (\%), and the higher the inhibition, the more effective the antimutagenic activities are (Maron and Ames, 1983). The inhibitory effects for one of the antimutagenicity results for the ACFs and silica gel with 1.0, 2.5 and $5.0 \mathrm{mg} /$ plate for $\mathrm{NQNO}$ and $\mathrm{AFB}_{1}$ are summarized in Table 5.

The his ${ }^{+}$revertants of strain against the NQNO in the blank (without ACFs or silica gel) were 521 for TA98 and 1000 for TA100, for AFB1: they were 1514 for TA98 and 2395 for TA100. The spontaneous revertants without NQNO were 46 for TA98 and 156 for TA100, and without $\mathrm{AFB}_{1}$ were 55 for TA98 and 160 for TA100. The his $^{+}$revertants of strain (inhibition) against the NQNO for silica gel were $493-558$ ( -5.68 to $-7.79 \%)$ for TA98 and $963-7062$ ( -7.34 to $8.65 \%)$ for TA100. For $\mathrm{AFB}_{1}$, they were $1509-1583(-4.72$ to $3.84 \%)$ for TA98 and 2418-2584 (-8.46 to $-1.03 \%)$ for TA100. The results also showed that for all ACFs, the his ${ }^{+}$revertants of strain (inhibition) against the NQNO were 514-546 (-5.33 to $1.47 \%$ ) for TA98 and $980-1023$ ( -2.76 to $2.41 \%$ ) for TA100. For $\mathrm{AFB}_{1}$ with TA98, it was $1526-1573$ ( -4.02 to $-0.80 \%$ ) and with TA100, it was 2293-2455 (1.77 to

Table 5. Antimutagenicity of silica gel and various ACFs toward Salmonella typhimurium TA98 and TA100 without the S9 (-S9) or with the S9 (+S9) mix

\begin{tabular}{|c|c|c|c|c|c|c|c|c|c|}
\hline \multirow[b]{2}{*}{ Specimen } & \multirow{2}{*}{$\begin{array}{c}\text { Amount } \\
\text { (mg/plate) }\end{array}$} & \multicolumn{4}{|c|}{ NQNO (1 $\mu \mathrm{g} /$ plate) } & \multicolumn{4}{|c|}{ AFB1 (5 $\mu \mathrm{g} /$ plate) } \\
\hline & & TA98 & $\begin{array}{c}\text { Inhibition }^{1)} \\
(\%)\end{array}$ & TA100 & $\begin{array}{c}\text { Inhibition } \\
(\%)\end{array}$ & TA98 & $\begin{array}{c}\text { Inhibition } \\
(\%)\end{array}$ & TA100 & $\begin{array}{l}\text { Inhibition } \\
(\%)\end{array}$ \\
\hline blank $^{2)}$ & 0.0 & $521(28)^{a 3)}$ & 0.00 & $1000(31)^{\mathrm{a}}$ & 0.00 & $1514(36)^{\mathrm{a}}$ & 0.00 & $2395(38)^{\text {abc }}$ & 0.00 \\
\hline \multirow{3}{*}{ Silica gel } & 1.0 & $548(62)^{\mathrm{a}}$ & -5.68 & $1062(53)^{\mathrm{a}}$ & -7.35 & $1509(78)^{\mathrm{a}}$ & 0.34 & $2584(73)^{b}$ & -8.46 \\
\hline & 2.5 & $493(37)^{\mathrm{a}}$ & 5.89 & $963(58)^{\mathrm{a}}$ & 4.38 & $1458(55)^{\mathrm{a}}$ & 3.84 & $2418(79)^{\mathrm{a}}$ & -1.03 \\
\hline & 5.0 & $558(35)^{\mathrm{a}}$ & -7.79 & $967(39)^{\mathrm{a}}$ & 3.91 & $1583(64)^{\mathrm{a}}$ & -4.73 & $2487(84)^{\mathrm{ab}}$ & -4.12 \\
\hline \multirow{3}{*}{ ACF-N800 ${ }^{4)}$} & 1.0 & $546(32)^{\mathrm{a}}$ & -5.33 & $990(67)^{\mathrm{a}}$ & 1.18 & $1561(42)^{\mathrm{a}}$ & -0.14 & $2293(87)^{\mathrm{a}}$ & 4.56 \\
\hline & 2.5 & $539(27)^{\mathrm{a}}$ & -3.79 & $995(38)^{\mathrm{a}}$ & 0.59 & $1544(44)^{a}$ & -2.06 & $2365(56)^{\text {abc }}$ & 1.34 \\
\hline & 5.0 & $532(36)^{\mathrm{a}}$ & -2.32 & $1023(31)^{\mathrm{a}}$ & -2.73 & $1528(38)^{\mathrm{a}}$ & -0.94 & $2379(47)^{\text {abc }}$ & 0.72 \\
\hline \multirow{3}{*}{ ACF-L800 } & 1.0 & $550(25)^{\mathrm{a}}$ & -6.04 & $992(41)^{\mathrm{a}}$ & 0.95 & $1569(29)^{\mathrm{a}}$ & -3.77 & $2345(49)^{\text {abc }}$ & 2.24 \\
\hline & 2.5 & $514(19)^{\mathrm{a}}$ & 1.47 & $1019(64)^{\mathrm{a}}$ & -2.25 & $1526(70)^{\mathrm{a}}$ & -0.82 & $2455(63)^{\text {abc }}$ & -2.68 \\
\hline & 5.0 & $517(17)^{\mathrm{a}}$ & 0.84 & $949(43)^{\mathrm{a}}$ & 6.04 & $1573(36)^{\mathrm{a}}$ & -4.04 & $2349(53)^{\text {abc }}$ & 2.06 \\
\hline \multirow{3}{*}{ ACF-R800 } & 1.0 & $523(40)^{a}$ & -0.42 & $983(54)^{a}$ & 2.01 & $1523(43)^{a}$ & -0.62 & $2341(44)^{\text {abc }}$ & 2.42 \\
\hline & 2.5 & $541(26)^{\mathrm{a}}$ & -4.14 & $980(39)^{\mathrm{a}}$ & 2.37 & $1563(49)^{\mathrm{a}}$ & -3.36 & $2342(52)^{\mathrm{abc}}$ & 2.37 \\
\hline & 5.0 & $536(57)^{\mathrm{a}}$ & -3.09 & $1006(49)^{\mathrm{a}}$ & -0.71 & $1572(43)^{\mathrm{a}}$ & -3.98 & $2323(79)^{\text {abc }}$ & 3.22 \\
\hline \multicolumn{2}{|c|}{ Spontaneous revertants } & \multicolumn{2}{|c|}{46} & \multicolumn{2}{|c|}{156} & \multicolumn{2}{|c|}{55} & \multicolumn{2}{|c|}{160} \\
\hline \multicolumn{10}{|c|}{$\begin{array}{l}\text { Inhibition }(\%)=\left[1-\left(\text { Number of his }{ }^{+} \text {revertants in the presence of the ACF of silica gel - Number of spontaneous revertants) }\right.\right. \\
\left.\left.\text { (Number of his }{ }^{+} \text {revertants in the absence of the ACF of silica gel - Number of spontaneous revertants }\right)\right] \times 100 \\
{ }^{2)} \text { blank (the control group) : the specimen was without silica gel or ACFs } \\
{ }^{3)} \text { Mean (standard deviation) within a transverse with the different superscripts are significantly different }(\rho<0.05) \text { by Duncan's multiple } \\
\text { range tests }\end{array}$} \\
\hline
\end{tabular}


4.55\%). The test groups and blank were compared by Duncan's Analysis. The results showed that the antimutagenicity against strains for the ACFs and silica gel displayed insignificant differences between his+ revertants and the blank. In other words, the ACFs and silica gel, a dose-dependent inhibitory from 1.0 to $5.0 \mathrm{mg} /$ plate, does not affect either $\mathrm{NQNO}_{\text {or }} \mathrm{AFB}_{1}$ in TA98 and TA100.

In this study, the ACFs showed no cytotoxicity (Table 3)/mutagenicity (Table 4), and were without antimutagenic effect (Table 5) against strains. These suggests the safety of the ACFs primarily as a material for food use.

\section{Hygroscopic ability of WACFP}

Water activity (Aw) is usually defined as the percent of relative humidity generated in equilibrium with the product in a closed system at a constant temperature, and indicates the amount of water in the total water content available to micro-organisms (Chang et al., 2006); that is, each of the species of micro-organisms (bacteria, yeast and mold) has its own minimum Aw. Furthermore, the Aw control is an important factor for the chemical stability of foods. Table 6 shows the results of Aw and maximum percent weight of WACFP and silica gel in high/low relative humidity conditions at either 90 or $40 \%$ with a constant temperature of $25^{\circ} \mathrm{C}$. The $\mathrm{AW}$ of the blank, without ACFs or silica gel, was 0.42. The Aw of all WACFPs found by adding different percent weights of ACFs was 0.41-0.45, which was higher than that for silica gel at 0.36 . The Aw of WACFP was lower than that of micro-organism growth (0.60). The growth of micro-

Table 6. Water activity and maximum percent weight of WACFP and silica gel in high/low relative humidity conditions at either 90 or $40 \%$ with a constant temperature at $25^{\circ} \mathrm{C}$

\begin{tabular}{|c|c|c|c|}
\hline \multirow{2}{*}{ Specimen } & \multirow{2}{*}{ Aw ${ }^{1)}$} & \multicolumn{2}{|c|}{ Maximum percent weight (\%) } \\
\hline & & $\mathrm{RH}^{2)} 90 \%$ & RH $40 \%$ \\
\hline blank $^{3)}$ & $0.42(0.00)^{4)}$ & $17.65(2.27)^{\mathrm{aA} 15)}$ & $5.10(0.12)^{\mathrm{aA} 1}$ \\
\hline WACFP-N10 ${ }^{6)}$ & $0.43(0.01)$ & $21.00(0.33)^{\mathrm{b}}$ & $5.54(0.36)^{\mathrm{b}}$ \\
\hline WACFP-N30 & $0.41(0.00)$ & $24.00(0.86)^{c}$ & $6.01(0.16)^{c}$ \\
\hline WACFP-N50 & $0.43(0.00)$ & $26.50(0.58)^{\mathrm{d}}$ & $6.36(0.20)^{\mathrm{c}}$ \\
\hline WACFP-L10 & $0.40(0.01)$ & $20.34(0.50)^{\mathrm{B}}$ & $5.50(0.29)^{\mathrm{B}}$ \\
\hline WACFP-L30 & $0.45(0.01)$ & $23.26(0.56)^{\mathrm{C}}$ & $6.00(0.06)^{\mathrm{C}}$ \\
\hline WACFP-L50 & $0.45(0.00)$ & $26.09(0.67)^{\mathrm{D}}$ & $6.25(0.07)^{\mathrm{C}}$ \\
\hline WACFP-R10 & $0.42(0.02)$ & $18.74(0.53)^{1}$ & $5.43(0.29)^{2}$ \\
\hline WACFP-R30 & $0.43(0.01)$ & $20.78(1.11)^{2}$ & $5.97(0.06)^{3}$ \\
\hline WACFP-R50 & $0.43(0.01)$ & $23.73(0.72)^{3}$ & $6.14(0.08)^{3}$ \\
\hline Silica gel & $0.36(0.00)$ & $37.20(0.10)$ & $11.70(0.17)$ \\
\hline \multicolumn{4}{|c|}{$\begin{array}{l}\text { 1) Aw: Water activity; }{ }^{2)} \mathrm{RH} \text { : Relative humidity; }{ }^{3)} \text { blank (without } \\
\text { ACFs or silica gel); }{ }^{4)} \text { Mean (standard deviation); }{ }^{5} \text { Mean } \\
\text { (standard deviation) separation within column to blank with } \\
\text { different alphabet and number are significantly different } \\
\text { ( } \rho<0.05 \text { ) by Duncan's multiple range tests; }{ }^{6)} \text { Abbreviations } \\
\text { see the Table } 1\end{array}$} \\
\hline
\end{tabular}

organisms is no longer possible when the Aw is below 0.65-0.95 (Chang et al., 2006).

The results of hygroscopicity for WACFP by adding 10, 30, and 50\% ACFs or silica gel at either RH 40 or $90 \%$ are also shown in Table 6 . The maximum percent weight of WACFP at RH 90\% was 18.74 to $26.50 \%$, higher than that of silica gel at $37.20 \%$. For RH $40 \%$, the maximum percent weight of WACFP was 5.43-6.36\%, higher than that of silica gel at $11.07 \%$. It is indicated that no matter what the $\mathrm{RH}$ is, the maximum percent weight of WACFP is lower than that of silica gel, but higher than that of the blank. According to Duncan's Analysis, at either RH 40 or $90 \%$, the maximum percent weights of WACFP and the blank were obviously different, and the increase by adding amounts of ACFs to WACFP was a higher maximum percent weight.

\section{Absorption and desorption of WACFP}

To evaluate the hygroscopicity change from absorption to desorption, the percent of absorption and desorption for WACFP and silica gel were investigated. WACFP and silica gel were conditioned with high humidity at $\mathrm{RH}$ of $90 \%$ and temperature at $25^{\circ} \mathrm{C}$ and then, the percent of absorption at the period of time (114 days) was measured. As shown in Fig. 1, while the specimens reached a saturated situation, the percents of absorption for WACFP-N30, WACFP-L30, WACFP-R30 and silica gel were $18.30,19.60,20.71$ and $22.08 \%$, respectively. The resulting specimens were continuously conditioned with a lower $40 \% \mathrm{RH}$ at $25^{\circ} \mathrm{C}$. The percent of desorption was 5.27, 5.72 and $7.31 \%$ for WACFP-N30, -L30 and -R30, but $15.33 \%$ for silica gel. The difference in absorption/ desorption percentages for WACFP with different types of ACFs was from $13.30 \%$ to $13.88 \%$, and after Duncan's Analysis, the percents of desorption at three measured periods for WACFP were insignificant, but obviously different than silica gel at $7.19 \%$. This indicated that the ability of absorption and desorption of WACFP is better than that of silica gel. Especially hygroscopicity was changed from absorption to desorption; the percent of desorption for WACFP reduced faster than that for silica gel.

To demonstrate the tested saturated WACFP with different temperature desorptions decreased faster than silica gel, the percent weight of WACFP with adding 30\% ACFs and silica gel was investigated from saturated situ-

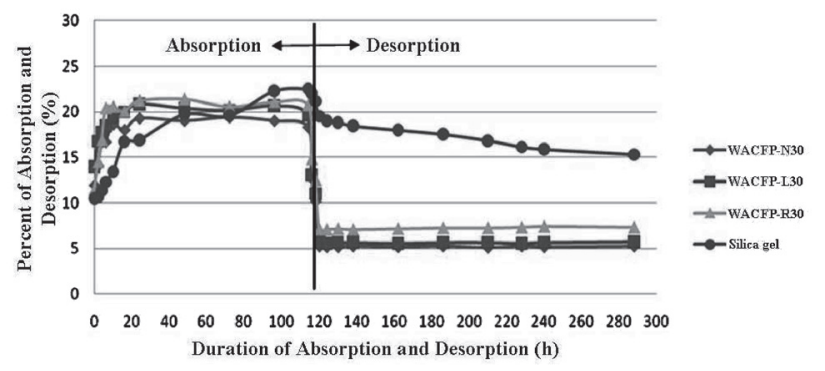

Fig. 1. Percent of Absorption and desorption of silica gel and WACFP with $30 \%$ of ACFs Legend: Abbreviations see the Table 1. 


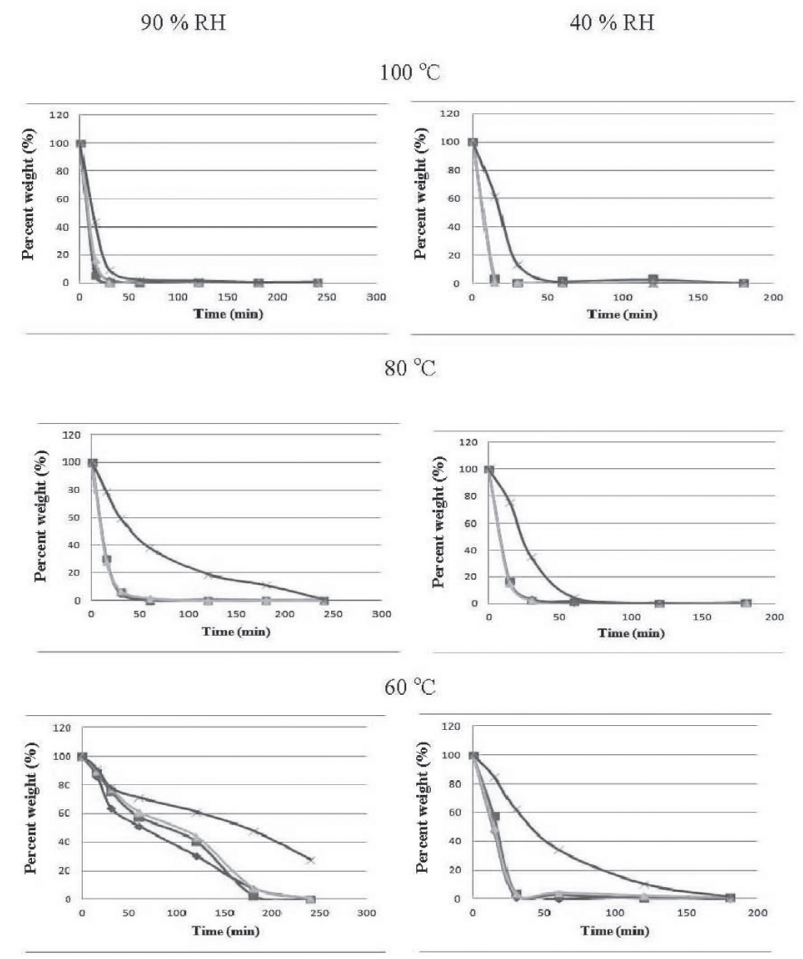

Fig. 2. Weight percent of WACFP with adding $30 \%$ of ACFs and silica gel with different temperature desorption Legend: $\bullet-$ : WACFP-N30; - - : WACFP-L30; WACFP-R30; $*$ : Silica gel; Abbreviations see the Table 1

ation conditioning during $\mathrm{RH} 90 \%$ or $40 \%$ at a desorption state with different temperatures at 60,80 , and $100^{\circ} \mathrm{C}$. The results are shown in Fig. 2. The percent weight of three types of WACFP with $100^{\circ} \mathrm{C}$ was no different, reaching a state of absolute dryness after about $30 \mathrm{~min}$, but for silica gel this took about $60 \mathrm{~min}$. At 60 and $80^{\circ} \mathrm{C}$, the WACPF had about the same desorption time to reach the state of absolute dryness, and the silica gel needed a longer period by more than four times, indicating that the percent weight of the tested saturated WACFP with different temperature desorptions decreased faster than that of silica gel. In other words, because the change for the percent of absorption and desorption is able to keep or liberate the moisture for food during the different $\mathrm{RH}$ environments, the WACFP as a moisture-proof material is probably safe to use for food storage, and it is said that the hygroscopic ability of WACFP is better than that of silica gel from the results of this study.

\section{CONCLUSIONS}

ACFs were prepared from NUKP, LUKP and cardboard using the method of physical activation with steam. The yield of ACFs was 10.85 to $13.66 \%$, the range of iodine number was between 647.38 and $1060.97 \mathrm{mg} / \mathrm{g}$, the specific surface area was from 262.03 to $877.21 \mathrm{~m}^{2} / \mathrm{g}$ and the average pore diameter was 2.14 to 5.38 (nm). ACFs showed neither cytotoxicity nor mutagenicity toward S. typhimurium TA98 and TA100 with or with- out the S9 mix, and expressed a dose-dependent inhibitory effect at $1.0-5.0 \mathrm{mg} /$ plate against both NQNO and $\mathrm{AFB}_{1}$ in $S$. typhimurium TA98 and TA100, indicating that the safety of biological action for ACFs can primarily be regarded as a material for food use. WACFP was made with 10, 30 and 50\% percent weight of ACFs. The Aw of WACFP was from 0.40 to 0.45 . The hygroscopicity of the WACFP was higher than that of the blank (without ACFs) in $\mathrm{RH} 90 \%$ or $\mathrm{RH} 40 \%$ at $25^{\circ} \mathrm{C}$, and it was lower than that of silica gel. The percent of desorption for WACFP reduced faster than that for silica gel, demonstrating that for saturated WACFP with different temperature desorption, the change in moisture content decreased faster than that for silica gel. This indicated that WACFP with ACFs prepared from NUKP, LUKP or cardboard can be a potential moisture-proof material for food use.

\section{ACKNOWLEDGEMENTS}

The authors are grateful to the Hou-li Mill, Cheng Loong Corporation, Taiwan for providing the experimental materials. We offer our sincere appreciation to the National Science Council through Grant No. NSC 99-2221-E-415 -002 for financial support.

\section{REFERENCES}

Ames, B. N., J. McCann and E. Yamasaki 1975 Methods for Detecting Carcinogens and Mutagens with the Salmonellal Mammalian-microsome Mutagenicity Test. Mutat. Res., 31 347-364

Asakura, R., M. Morita, K. Maruyama, H. Hatori and Y. Yamada 2004 Preparation of Fibrous Activated Carbons from Wood Fiber. Journal of Materials Science, 39: 201-206

Barrett, E. P., L. G. Jaoyner and P. P. Halenda 1951 The Determination of Pore Volume and Area Distributions in Porous Substances - I. Computations from Nitrogen Isotherms. J. Am. Chem. Soc., 73: 373-80

Chang, W. T., M. T. Lee, M. M. Ru, G. W. Chang, S. T. Chen, R. S. Sun, E. H. Chen, S. W. Chen, C. S. Shiea, S. S. Lin and S. W. Lin 2006 Food Chemistry. National Taiwan Edition, pp. 20-26

Chen, H. B. 2003 Manufacturing of Bamboo Charcoal and Activated Carbon. Department of Wood Science and Design, National Pingtung University of Science and Technology, Master thesis, pp. 2-36

Hsieh, C. T. and H. Teng 1999 Effect of Adsorption Capacity for Mesopore Activated Carbon in Liquid Phase. J. Chem. Eng., 46(6): $92-100$

Huang, W. J., M. H. Duh and H. C. Lin 2010 Investigation of Absorption Properties of Activated Carbon Fibers Prepared from Nadelholz/Laubholz Pulp. J Agric. For., 7(1): 16-31

$\mathrm{Hu}$, Z. and M. P. Srinivasan 1999 Preparation of High-surfacearea Activated Carbons from Coconut Shell. Micro. Meso. Mat., 27: 11-18

Lin, H. C., Y. C. Weng, G. S. Hwang and N. Fujimoto $2014 \mathrm{a}$ Adsorption and Preliminary Safety Evaluation of Activated Carbons Refined from Charcoals. J Fac Agr, Kyushu Univ., 59(1): 117-125

Lin, H. C., L. Y. Tseng, Y. J. Lai, S. C. Wu and N. Fujimoto 2014b Biological Safety Assessment of Functional Activated Carbons Prepared from Three Agricultural Wastes. J Fac Agr, Kyushu Univ., (In published).

Liou, J. F. 2012 Development and Utilization of Activated Carbon Fibers Paperboard as a Food Moisture-proof Material. Department of Forest Products Science and 
Furniture Engineering, National Chiayi University, Master thesis

Lua, A. C. and J. Guo 2000 Activated carbon prepared from oil palm stone by one-step $\mathrm{CO}_{2}$ activation for gaseous pollutant removal. Carbon, 38: 1089-1097

Maron D. M., and Ames, B. N. 1983 Revised Methods for the Salmonella Mutagenicity Test. Mutat. Res., 113: 173-215

McCann, J., E. Choi, E. Yamasaki and B. N. Ames 1975 Detection of Carcinogens as Mutagens in the Salmonella/Microsome Test: Assay of 300 Chemicals. Proc Natl Acad Sci U S A., 72(12): 5135-5139

National Poison Center 1990 Desiccating agent. Ministry of Health and Welfare, Toxicology, $\mathbf{6}: 2-3$

Ministry of Health and Welfare 1999 The Health Food Safety Assessment Method. Ministry of Health and Welfare, Executive Yuan, Taiwan ROC

Sugimura, T., S. Sato, M. Nagao, T. Yahagi, T. Matsushima T. and Y. Seino 1976 Overlapping of Carcinogens and Mutagens. Fundam Cancer Prev Proc Int Symp Princess Takamatsu Cancer Res Fund 6 $6^{\text {th }}$ 1975: pp. 191-215.

Srinivasakannan, C. and M. Z. A. Bakar 2004 Production of Activated Carbon from Rubber Wood Sawdust. Biomass and Bioenergy, 27: 89-96

Tseng, L. Y., S. C. Wu and H. C. Lin 2007 Mutagenic Evaluation and Physical Absorption Properties of Corn Cob, Bagasse Pith and Mushroom Stalk Activated Carbon. J Agric. For., 4(2) $1-17$

Waleh, N. S., S. J. Rapport and K. E. Mortelmans 1982 Development of a Toxicity Test to be Coupled to the Ames Salmonella Assay and the Method of Construction of the Required Strains. Mutat. Res., 97: 247-256

Wang, C. K. 2004 Effects on the Basic Properties and Ability of Carbonization of Taiwan Giant Bamboo and Bamboo Carbonized Materials, School of Forestry and Resource Conservation, National Taiwan University, Master thesis, pp. 25-38

Williams, P.T. and A. R. Reed 2006 Development of Activated Carbon Pore Structure via Physical and Chemical Activation of Biomass Fiber Waste. Biomass Bioenergy, 30: 144-152

Yen G. C., P. D. Duh, Y. L. Hung 2001 Contributions of Major Components to the Antimutagenic Effect of Hsian-Tsao (Mesona procumbens Hemsl.), Journal of Agricultural and Food Chemistry. 49: 5000-5004.

Yun C. H., Y. H. Park and C. R. Park 2001 Effects of Precarbonization on Porosity Development of Activated Carbons from Rice Straw. Carbon, 39: 559-567

Zhang, T., W. P. Walawender, L.T. Fan, M. Fan, D. Daugaard and R. C. Brown 2004 Preparation of Activated Carbon from Forest and Agricultural Residues through $\mathrm{CO}_{2}$ Activation. Chemical Engineering Journal, 105: 53-59 